\title{
Sati tradition its origin and change as reflected in Around the World in 80 Days: A sociological approach
}

\author{
Zakiyyah Attasyriky ${ }^{\mathrm{a}, 1, *}$, Hendra Darmawan ${ }^{\mathrm{b}, 2}$ \\ ${ }^{\mathrm{a}, \mathrm{b}}$ Universitas Ahmad Dahlan Yogyakarta, Jl. Ringroad Selatan, Kragilan, Tamanan, Kec. Banguntapan, Bantul, Daerah Istimewa Yogyakarta 5519, \\ Indonesia \\ ${ }^{1}$ zakiyyah015@gmail.com*; ${ }^{2}$ hendra.darmawan@pbi.uad.ac.id \\ * corresponding author
}

ARTICLE INFO

\section{Article history}

Received 1 December 2019

Revised 5 March 2020

Accepted 8 August 2020

Available online 15 January 2021

Keywords

disobedience

sociological approach

around the world in 80 days

\section{ABSTRACT}

This research aims at investigating the main character's disobedience toward Sati tradition in Around the World in 80 Days: a Sociological Approach. The research method used in this research is a descriptive qualitative method so the researcher analyzes the data in this research through description. There are two main results of this research. First, the main character's disobedience toward Sati tradition are (1) the main character's disobedience in India Forest (being displeased with government authority, hope of reform); (2) the main character's disobedience in Calcutta (law enforcement); (3) the main character's disobedience in United States of America (injustice occur). Second, the moral values can be taken from the novel are divided into positive and negative values.

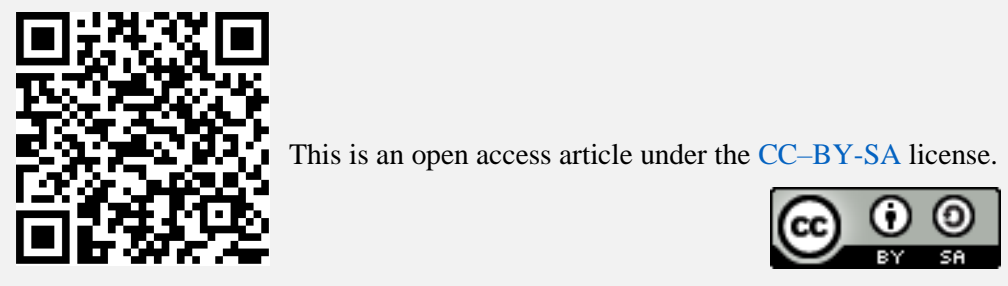

\section{Introduction}

India is a land of ancient civilization. India's social, economic, and cultural configurations are the products of a long process of regional expansion. One of the Hindu doctrines obtained by Indians at that time was Sati Tradition. Then this tradition was carried out and obeyed by Indians as a symbol of loyalty. This tradition comes from the story of a goddess in India named Dewi Sati or Dewi Dakshayani. Dewi Sati or Dakshayani was known for her self-sacrifice by plunging herself into the funeral pyre, she was unable to resist the humiliation of Dhaksa (her father), against Siva (her husband). After self-immolation and death, Dakshayani was reincarnated, and she was born for the second time. The story of the perfect loyalty of Dewi Sati to Siva, her husband, is often cited to justify the origin of Sati practice in India. A practice that describes a wife's last form of loyalty by sacrificing herself in the cremation of a husband's escape. From the story of this tradition, many Indian women follow this tradition as a symbol of loyalty. This tradition was officially abandoned during British rule in 1829.

The reason of Jules Verne (2015) as a writer of the novel Around The World in 80 Days tells about Sati tradition because there are many countries that do not know in India there are dangerous traditions especially for women. Besides that, Verne wants to call for equal rights for women, without any differences on the basis of sex. The high level of discrimination of women in India is rooted in tradition and culture, which embodies men and overrides women in their social system. Jules Verne hopes, by writing this novel it can reduce some dangerous practice in India and can eliminate all forms of discrimination against women. 
In relation to literary work, the researcher used a sociological approach as a way of analyzing an Indian culture called the Sati tradition. Both of them learn about the events and relationships experienced by people or humans. Laurenson and Swingewood (1972) added that literary work is considered as an attempt to recreate human relations with family, society, politics, religion, etc. Because it allows an alternative aesthetic aspect to adjust and make changes in society. Literary works are able to summarize a number of events which can be explained systematically and in detail through sociological methods, which are then referred to as literary sociology.

The researcher is interested to analyze Around the World In 80 Days by Jules Verne because of several reasons. First, it was one of Jules Verne's novels that reached the best-seller as an adventure genre novel. The second, the story is interesting. It tells about an adventure of Phileas Fogg as the main character in this novel when traveling the world in 80 days and seeing various events in various countries. The third is because the researcher finds a Sati tradition in India that is quite interesting from the novel and inspiring to know. In this research the researcher analyzed the main character's disobedience toward Sati tradition. The researcher tried to analyze Aouda as the main female character using sociological approach because if Aouda refused to follow the Sati tradition, she would be considered despicable, and her life would be miserable in her environment.

\section{Research Method}

The research method used in this research is a descriptive qualitative method. According to Hanchock (2009: 24) on An Introduction to Qualitative Research, qualitative research is concerned to explain social phenomena. It uses other's accounts as data and focuses in identifying incorporeal factors, such as social norms, socioeconomic status, gender roles, ethnicity, and religion. Then, the researcher gets the data from several sources which are Around the World in 80 Days, Murderous Ritual versus Devotional Custom: The Ritual of Sati and Women's Subjectivity, and Conformity, Obedience, Disobedience: The Power of the Situation (Barnali, 2014).

Since this research is a kind of descriptive qualitative research, there are so many data that should be gained. In collecting data for this research, the researcher employed the library research completed in several steps. Firstly, the researcher read the novel several times intensively to understand the content of the novel and to find out the object under study, that was the main character's disobedience toward Sati tradition in Jules Verne's Around the World in 80 Days. After reading the novel, the researcher outlined the research to analyze the novel. From the outline, some sources were gathered from libraries, journals, articles, and internet relevant to the research topic.

The collected data were analyzed under a sociological approach and it was described using a descriptive qualitative method. Based on Nassaji in Qualitative and Descriptive research: Data type versus Data Analysis, the aim of descriptive research is to describe a phenomenon and the characteristics of it. This is more concerned with what than how or why a phenomenon happened (2015: 1). Descriptive method is the interpretation to the content and arranged systematically to describe the main data related to the topic. The qualitative research is categorized data into patterns as the primary data for organization and reporting research. In this qualitative method the description of the contents or documents will be obtained. The point of qualitative is the novel entitled Around the World in 80 Days by Jules Verme.

\section{Findings and Discussion}

\subsection{The main character's disobedience in India Forest}

\section{1) Being displeased with government authority}

When going through Indian forest, the conflict comes. According to Dahrendorf (2015: 75) conflict arises when external goals are not in harmony. In this novel, Phileas Fogg could not find a transportation route in that place. Phileas Fogg was annoyed by the authority of the Indian government, which did not provide access to travel to the Indian Forest. While in the newspaper, there was a railroad run all through India.

"Indeed you still run into trouble over your servant's behavior at the pagoda. The government protects Indian religions and custom very strictly." 
"Where are we?” asked Phileas Fogg

"At the village of Kholby, replied the conductor. "The railroad isn't finished. There is no track between here and Allahabad, a distance of 50 miles" (Verne, 1874: 64).

“This is a terrible delay for you Mr Fogg," said Sir Francis (Verne: 1874: 66).

Sir Francis Cromarty explained that the Indian government maintained a strict tradition carried out in Indian forests. Phileas Fogg are in an ambiguous state, it is clearly explained as a liminal phase. According to Turner (1974: 4) liminal phase is the stage where the migrant experiences an ambiguous state. Where he was not in his original tradition and was not in the tradition he was experiencing at this time.

They passed through an area people by fierce tribes with savage custom. Suddenly, the elephant stopped. Loud voices come through the trees.

"A procession of Brahmins is heading this way," said Parsee.

"Let's hide! Brahmins are the priest of the Indian religion of Hinduism. (Verne, 1874: 66)

In Indian Forest, it is the first time Phileas Fogg sees the procession of Sati. He was shocked by the culture that was in front of him, because it is the first time he sees a tradition of a From the citation above it can be seen that Phileas Fogg does not agree with Sati tradition. Phileas Fogg was angry; he questioned why this immoral tradition still exists in an English colony. From this incident, the researcher related to the theory of travelling by Said (1991). Theory of traveling serves to trace hidden aspects so that it can be seen how the power works. On the other hand, it dismantles the discipline, institutions, and underlying ideology. That tradition is hidden, and the Indians did not want everyone to know. Phileas Fogg and others must hide in the deep of forest so that the procession of Brahmins would not be known. The ritual of Sati is described in the quotation below human sacrifice. Based on Ward (2001: 10) this situation is called culture shock. Culture shock is an active process in dealing with change when in an unfamiliar environment. Phileas Fogg saw this tradition while hiding behind the trees.

Soon the priest came into view, followed by a large crowd of people chanting. Carried along on a platform was a statue of the Hindu goddess Kali, with four arms and red body. The brahmins also dragged along a young woman dressed in a beautiful robe and jewelry. She had very light skin and looked more like a European than an Indian. Behind her came men holding sabers and guns, and carrying the body of an old man dressed like a Hindu prince. The parsee explained that the body was that of the young womans' husband, who was an Indian rajah, or prince (Verne, 1873:79).

From the quotation above, it can be seen that Sati tradition is done by forcing the wife to use opium, so she faltered at every step. She lost her consciousness as an effect from opium and she has no strength to make any resistance. Phileas Fogg was surprised that the Sati tradition is not voluntary, but it was done by forcing the victim to use opium. It is the opposite of western culture; in western culture the wife can marry again when their husband has died. On the contrary, Indian culture still sees tradition as something to do even if it is outside the rational of human beings.

\section{2) Hope of Reform}

Phileas Fogg tried to disobey this tradition in order to save Aouda from the human sacrifice. According to Glaeser (2015: 2), they break the law in order to register their protest, often with hope of increasing the likelihood of significant reform. This form of Phileas Fogg's disobedience aims to stop this tradition, so that no more sacrifice are made by force.

"The woman will be taken to a pagoda to spend the night," said the Parsee. "Tomorrow at dawn, she will be burned alive as a human sacrifice to the gods!"

"I have 12 hours to spare," cried out Phileas Fogg. "Let us stop and save this woman!" (Verne, 1873:70)

To save Aouda, Phileas Fogg and his servant Passepartout tried to sneak in, and they waited until nightfall. But the pagoda was guarded by many guards. 
The would-be rescuers hid in the trees near the pagoda to await nightfall. They hoped to slip past the Brahmins into the pagoda, but guards with torches and sabers stood at all the entrances. (Verne, 1873: 83)

When Phileas Fogg try to find an idea to save Aouda. Passepartout has an idea of disguising himself as an old rajah.

Passepartout, noticing that the Brahmins were drunk, began to work on another plan of rescue. Suddenly, cries of terror came from the crowd. The old rajah was alive! He stood up, took his wife in his arms, and, surrounded by fire and smoke, climbed down from the funeral pyre. He walked over and took Phileas Fogg and said, "Let us be off!" (Verne, 1873:74)

Passepartout was the "rajah". In the moments before dawn, under cover of darkness, he had hidden the body of the real rajah and placed himself on the funeral pyre instead (Verne, 1873:74)

Finally, with Passepartout and Phileas Fogg's teamwork they can save Aouda from sati tradition.

\subsection{The main character's disobedience in Calcutta}

\section{1) Law enforcement}

Aouda feels sorry to Phileas Fogg and Passepartout for being involved with the police, then she asked them to continue her journey and leave her.

"Leave me here and go," said Aouda. "If you hadn't rescued me, you would not be in this prison." (Verne, 1873:84)

Phileas Fogg did not accept the arrest. The judge must not sue him just because he saved someone's life from death. He began to explain why he disobey Sati tradition and try to take Aouda from this tradition. According to Rawls (2013: 7), the purpose of this civil disobedience is to call attention to an unjust law and appeal to public sense of justice.

"I admit our guilt," Fogg said, "but the priest were about to perform a human sacrifice!"

"That's right," added Passepartout. "These priest are from the pagoda of Pillaji." (Verne, 1873:84)

According to Glaeser (2015: 2) disobedient people indicate that they are unhappy with the governing authority, and in particular that the authority is responsible for serious mistakes and injustices. After the judge listened to Phileas Fogg's explanations and protests about the traditions in Indian Forest and Bombay, the judge's decision is they have to spend 15 days in the jail and pay a fine 300 pounds.

"Since you have admitted your guilt," the judge told Passepartout, "and since English law protects Indian religions very strictly, I order you to spend 15 days in jail and pay a fine of 3000 pounds." (Verne,1873:86)

"I offer bail," declared Phileas Fogg.

"All right," said the judge, "but the bail will be 1,000 pounds for each man. And if you leave India before your sentence is up, the money will not be returned." (Verne, 1873: 86)

\subsection{The main character's disobedience in United States}

\section{1) Injustice occurred}

Colonel Stramp Proctor still forced Philleas Fogg for a duel. When they were ready with their weapons, suddenly a gunshot from outside of the train appeared and it was an attack from a band of Sioux Indians. A band of Sioux was an Indian tribe who likes to attack immigrants by robbing their wealth and even killing them. Phileas Fogg and his servant assume that killing was not fair and does not appropriate with values they believe. According to Rawls (2013) civil disobedience theory focuses on resistance to the government for the injustices that occur. This caused injustice to the visitors because they felt insecurity. Phileass Fogg decided to resist a group of Sioux as a form of injustice he had received during the trip. Phileas Fogg tried to stop the train in order to fight the resistance from a band of Sioux Indians. 
"The train will be stopped!" said Passepartout. Before Phileas Fogg could stop him, he opened a door and slipped under the car. A few minutes later, the train came to a stop a few from Kearney station. (Verne, 1873:184)

When Phileas Fogg and other passengers tried to resist the resistance from band of Sioux India, Passepartout and two other passengers were missing.

By holding onto the metal chains under the cars, Passepartout had managed to swing from the back end of the train to the front. He loosened the safety chain that joined the engine to the other cars and the jolts of the swiftly moving train broke the engine loose. When the train came to a stop by Fort Kearneyi, however, Passepartout and two other passengers were missing. (Verne, 1873:187)

Phileas Fogg will save Passepartout and two other passengers who have been kidnapped by a band of Sioux.

"The lives of three men are at stake," Fogg insisted.

"That may be true, but I cannot risk the lives of 50 or 100 men to save there."

"Very well, then I will go alone!"

"You can't handle Indians alone!"

"do you expect me to let Passepartout die after he saved all of our lives?" asked Fogg

"You are a brave man. I will send 30 men to help you," said the commander. (Verne, 1873: 188)

Aouda and Fix waited anxiously for Phileas Fogg return. But at dawn, Phileas Fogg and the prisoners appeared savely from the Forest.

The train speed off into the distance. Night came, and there was still no sign of Phileas Fogg and the soldiers. At dawn, the fort commander was ready to give up his soldiers as lost. Suddenly, they appeared in the distance, along with the prisoners. (Verne, 1873:190)

\subsection{Moral Values}

The researcher found some moral values after analyzing the novel Around The World in 80 Days by Jules Verne. Based on Nurgiyantoro (1995: 30) moral value is something which the author wants to carry on the message to the readers by the meaning which implied in a work indirectly or by giving the suggested through the story. Moral values on this story will be divided into two. There are positive moral values and negative moral values.

\section{1) Positive Values}

Positive value means good attitudes of the moral values that readers can practice it in real life. The positive moral values can be taken from the story are stated as follows:

\section{a) Being Generous}

Being a generous person is a good moral. It is important to always help people in need as long as we are able to help them. Although Phileas Fogg is an introvert and unpredictable man, he is always generous to anyone with his wealth. The quotations below shown how Phileas Fogg generous to anyone:

Indeed, he hardly knew Phileas Fogg when the trip began. Nevertheless, he had seen Mr. Fogg's generosity in helping the beggar at London railroad station, giving the valuable elephant to the Parsee, and, above all, risking his fortune (and his life) to stop and rescue Aouda.(Verne, 1873: 114)

The quotations show that Phileas Fogg likes to help people. Phileas Fogg's generosity witnessed by his servant at the London railway station apparently still continues. While Phileas Fogg was on mission around the world in 80 days, he still took the time to help Aouda from the human-sacrifice tradition.

b) Being Calm in Any Situations 
To solve problems or when we are faced with problems, we should be able to solve it with good emotions. We will be able to think rationally when solving problems calmly. In Around the World in 80 Days by Jules Verne, an important moral value that is highlighted is calmness. Phileas Fogg is shown as being calm in any situation. He is a very organized and orderly person. He does not show his emotions easily.

It is proven when he goes on sea voyages that is dangerous. But Fogg stay calm and collected. The quotation below shown how Phileas Fogg does not get worried or disturbed:

By sunrise on November 8, the Tankadere had traveled more than 100 miles. Captain Bunsby. Eager for his reward, spared no effort to reach Shanghai on time. The following day, however, a terrible storm hit the ship. "it's a typhoon!" shouted the captain. "we must sail for the nearest port!"

"There is only one port of us," said Phileas Fogg calmly, "and that is Shanghai!" (Verne, 1873: 125)

On the quotation, we can take the value that we have to be calm to face various problems, because with the calmness you can think rationally.

\section{c) Uphold Justice Without Discrimination}

There is no difference in rights between men and women. Men and women should get equal treatment, equal respect, and equal opportunity. In the novel Around the World in 80 Days by Jules Verne, Phileas Fogg, the main character, tried to save Aouda from the Sati tradition because he did not agree to the oppression of women's rights in India. The quotation below shown how Phileas Fogg disobey the Sati tradition:

"The woman will be taken to a pagoda to spend the night," said the Parsee. "Tomorrow at dawn, she will be burned alive as a human sacrifice to the gods!"

"I have 12 hours to spare," cried out Phileas Fogg. "Let us stop and save this woman!" (Verne, 1873: 70)

On the quotation, we can take the value that if we see justice is not upheld, then fight it in any way until the justice stands again.

\section{2) Negative Values}

Negative moral values refer to bad attitudes that should be avoided by the readers. It is something we should not apply in a practical life. There are negative moral values that can be taken from Jules Verne's Around the World in 80 Days.

\section{a) It Is Not Good to be Careless}

Careless is a bad attitude that people should avoid, because being careless can harm yourself and others. Phileas Fogg's expectation to prove his statement that he is able to travel around the world in 80 days is block by a detective who is being careless. The detective followed Phileas Fogg and caught him on charges of bank robber when Phileas Fogg almost succeeded in his mission:

Fix was out of breath, and his clothes and hair were in disarray. "Sir," he stammerd, "sir--forgive me! The bank robber was arrested three days ago! You just looked a lot like him. Now you are free!"'Verne, 1873: 214)

Phileas Fogg walked up to Fix and, with a powerful blow of his arms, knocked him flat on the floor. Phileas Fogg was five minutes too late. The wager lost. (Verne, 1873: 216)

On the quotation, we can take the value that we have to avoid potential danger in doing things. Do not make decisions without clear consideration.

\section{Conclusion}

The research resulted in two findings. The first was the factors that cause the main character's disobedience. Those are being displeased with government authority, hope of reform, law enforcement, and injustice occurred. The second was the moral values that can be taken from the novel. They were divided into positive and negative values. The positive values included (1) be 
generous to every human who needs help while we are able to help them; (2) try to be calm to face any situations, because with the calmness you can think rationally to find a way out; (3) when you see justice is not upheld, fight it in any way until the justice stand again; (4) social protest is permissible with the aims of bringing about a better change in law and government policies. Meanwhile, the negative value we should avoid is that we should not be careless because being careless can harm yourself and others.

\section{References}

Barnali, S. (2014). Murderous ritual versus devotional custom: The ritual of Sati and women's subjectivity in Amitav Ghos's of Poppies. Humanities. 3, 283-298. doi:10.3390/h3030283

Dahrendorf, R. (2015). Class and class conflict in industrial society (classic Reprint). FORGOTTEN Books.

Glaeser, E.L., \& Sunstein, C. R. (2015). A theory of civil disobedience (No. w21338). National Bureau of Economic Research.

Hancock, B; Ockleford, E. \& Windridge, K. (2009). An Introduction to qualitative research. The NIHR RDS $\mathrm{EM} / \mathrm{YH}$.

Laurenson, D., \& Swingewood, A. (1972). The sociology of literature. Paladin.

Laurenson, Diana., \& Swingewood, Alan. 1972. The sociology of literature. New York: Schocken Books.

Nassaji, H. (2015). Qualitative and descriptive research: Data type versus data analysis. Language teaching research, 19 (2), 129-132. doi: https://doi.org/10.1177/1362168815572747

Nurgiyantoro, B. (1995). Teori pengkajian fiksi. Yogyakarta: Gadjah Mada University Press.

Rawls, J. (2013). The justification of civil disobedience. Arguing about law, 244-253.

Said, E. W. (1991). Musical elaborations. New York: Columbia University Press.

Turner, V. (1974). Dramas, fields, and metaphors: Symbolic Action in Human Society. Ithaca, NY: Cornell University Press.

Verne, J. (2015). Around the world in 80 Days. New York: Waldman Publishing Corp.

Ward, C. A., Bochner, S., \& Furnham, A. (2001). The psychology of culture shock. New York: Psychology Press. 